Jurnal Keperawatan Silampari

Volume 3, Nomor 1, Desember 2019

e-ISSN: 2581-1975

p-ISSN: 2597-7482

DOI: https://doi.org/10.31539/jks.v3i1.898

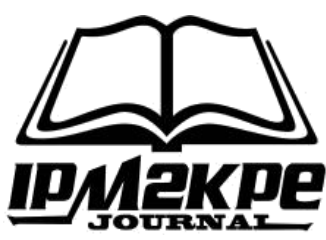

\title{
PENGARUH INTERVENSI STRATEGI PELAKSANAAN KELUARGA TERHADAP PENGETAHUAN DAN KEMAMPUAN KELUARGA DALAM MERAWAT KLIEN SKIZOFRENIA DENGAN HALUSINASI
}

\author{
Susilawati ${ }^{1}$, Larra Fredrika ${ }^{2}$ \\ Program Studi Ilmu Keperawatan, Universitas Muhammadiyah Bengkulu ${ }^{1}$ \\ Program Studi Profesi Ners, Universitas Muhammadiyah Bengkulu ${ }^{2}$ \\ susilawati@umb.ac.id ${ }^{1}$
}

\begin{abstract}
ABSTRAK
Penelitian ini bertujuan mengetahui pengaruh intervensi strategi pelaksanaan keluarga terhadap pengetahuan dan kemampuan keluarga dalam merawat klien Skizofrenia dengan halusinasi di RSKJ Soeprapto Bengkulu. Penelitian ini menggunakan metode quasi-eksperimental dengan desain one-group pre test and post test, dengan jumlah sampel sebanyak 15 responden. Hasil analisis terbukti ada pengaruh intervensi strategi pelaksanaan terhadap pengetahuan dan kemampuan keluarga ( $p$ value $=0,000$ ). Simpulan, intervensi strategi pelaksanaan keluarga merupakan hal yang sangat penting diperhatikan dan harus dilaksanakan sebagai bentuk intervensi untuk meningkatkan pengetahuan dan kemampuan keluarga dalam merawat klien Skizofrenia, sehingga klien yang sudah pulang ke rumah dapat dapat dirawat dengan baik dan benar oleh keluarga, dan keluarga dapat dengan segera memutuskan untuk klien kembali mendapatkan perawatan apabila terjadi kekambuhan.
\end{abstract}

Kata Kunci : Halusinasi, Keluarga, Skizofrenia, Strategi Pelaksanaan

\section{ABSTRACT}

This study aims to determine the effect of family implementation strategy interventions on family knowledge and ability to care for Schizophrenia clients with hallucinations in RSKJ Soeprapto Bengkulu. This study uses a quasi-experimental method with a onegroup pre-test and post-test design, with a total sample of 15 respondents. The results of the analysis proved that there was an influence of implementation strategy interventions on family knowledge and abilities ( $p$ value $=0,000$ ). Conclusion, family implementation strategy interventions are very important to note and must be implemented as a form of intervention to improve family knowledge and abilities in caring for Schizophrenia clients, so clients who have returned home can be cared for properly and correctly by the family, and the family can immediately decide for clients to get treatment again if there is a recurrence.

Keywords: Family, Schizophrenia, Hallucinations, Implementation Strategy 


\section{PENDAHULUAN}

Kesehatan jiwa suatu bagian yang tidak terpisahkan dari kesehatan atau bagian integral dan merupakan unsur utama dalam menunjang terwujudnya kualitas hidup manusia yang utuh. Sebagai bagian yang utuh dan kualitas hidup seseorang dengan memperhatikan semua segi kehidupan manusia. Kesehatan jiwa bukan sekedar terbebas dari gangguan jiwa, tetapi merupakan sesuatu yang dibutuhkan oleh semua orang mempunyai perasaan sehat dan bahagia serta mampu menghadapi tantangan hidup, dapat menerima orang lain sebagaimana adanya dan mempunyai sikap positif terhadap diri sendiri dan orang lain. Menurut Organisasi Kesehatan Dunia (WHO), Kesehatan jiwa merupakan suatu keadaan dimana seseorang yang terbebas dari gangguan jiwa, dan memiliki sikap positif untuk menggambarkan tentang kedewasaan serta kepribadiannya.

Orang yang mengalami gangguan jiwa sepertinya tinggal di negara berkembang, sebanyak 8 dari 10 penderita gangguan mental itu tidak mendapatkan perawatan, Masalah gangguan jiwa memang sudah menjadi masalah yang serius di seluruh dunia Diperkirakan ada sekitar 450 juta orang didunia yang mengalami gangguan kesehatan jiwa. Sementara itu di wilayah Asia Tenggara, hampir satu pertiga dari produk diwilayah ini pernah mengalami gangguan jiwa (WHO, 2012).

Kesehatan jiwa menurut UU No 23 tahun 1996 sebagai suatu kondisi yang memungkinkan perkembangan fisik, intelektual dan emosional yang optimal dari sesorang dan perkembangan itu berjalan secara selaras dengan keadaan orang lain. Mengemukakan bahwa kesehatan jiwa merupakan suatu kondisi mental yang sejahtera (mental wellbeing) yang memungkinkan hidup harmonis dan produktif. Penderita gangguan jiwa belum bisa disembuhkan $100 \%$, tetapi para penderita gangguan jiwa memiliki hak untuk sembuh dan di perilakukan secara manusiawi. Upaya kesehatan jiwa bertujuan untuk menjamin setiap orang dapat mencapai kwalitas hidup yang baik, menikmati kehidupan kejiwaan yang sehat,bebas dari ketakutan, tekanan gangguan lain yang dapat menggangu jiwa. Setiap individu beresiko mengalami gangguan jiwa ringan sampai gangguan jiwa berat. Salah satu gangguan jiwa yang terdapat diseluruh dunia adalah gangguan jiwa skizofrenia (Kemenkes, 2014).

Skizofrenia adalah gangguan yang terjadi pada fungsi otak. Skizofrenia sebagai penyakit neorologis yang mempengaruhi persepsi klien, cara berpikir, bahasa,emosi, dan prilaku sosialnya (Yosep, 2014). Indonesia mengalami peningkatan jumlah penderita skizofrenia cukup banyak, diperkirakan prevelensi skizofrenia di Indonesia pada tahun 2013 adalah 1.728 orang. Jumlah penderita skizofrenia di Indonesia ini terkait dengan tingginya stress yang muncul di daerah perkotaan. Adapun proposi rumah tangga yang pernah memasung ART gangguan jiwa berat sebesar 1.655 rumah tangga dari $14,3 \%$ terbanyak tinggal di pedesaan, sedangkan yang tinggi diperkotaan sebanyak 10,7\% (Riskesdas, 2013).

Diagnosa keperawatan dengan skizofrenia salah satunya adalah halusinasi. Halusinasi merupakan proses akhir dari pengamatan yang diawali oleh proses diterimanya stimulus oleh alat indera, kemudian individu ada perhatian, lalu diteruskan otak dan baru kemudian individu menyadari tentang sesuatu yang dinamakan persepsi. halusinasi disebabkan oleh jenis dan jumlah sumber yang dapat dibangkitkan oleh individu untuk mengatasi stress. Diperoleh baik dari klien maupun keluarganya, Faktor preposisi dapat meliputi faktor perkembangan, sosiokultural, biokimia, psikologis, dan generik (Yosep, 2013). 
Pengertian caregiver adalah seorang individu yang secara umum merawat dan mendukung individu lain (pasien) dalam kehidupannya. caregiver mempunyai tugas sebagai emotional support, merawat pasien (memandikan, memakaikan baju, menyiapkan makan, mempersiapkan obat), mengatur keuangan, membuat keputusan tentang perawatan dan berkomunikasi dengan pelayanan kesehatan formal.

Caregiver terdiri dari formal dan tidak formal, caregiver formal merupakan perawatan yang disediakan oleh rumah sakit, psikiater, pusat perawatan ataupun tenaga profesional lainnya yang diberikan dan melakukan pembayaran, sedangkan caregiver yang tidak formal merupakan perawatan yang dilakukan di rumah dan tidak profesional dan tanpa melakukan pembayaran seperti keluarga penderita yaitu istri/suami, anak perempuan/laki-laki, dan anggota keluarga lainnya. Caregiver dan carer adalah istilah yang sering digunakan untuk mengambarkan orang yang melakukan perawatan pada orang yang mengalami keterbatasan (Sarafino, 2014).

Caregiver pada masyarakat Indonesia umumnya adalah keluarga, dalam hal ini adalah pasangan, anak, menantu, cucu atau saudara yang tinggal satu rumah, atau lebih yang berbagi tempat tinggal atau berdekatan satu dengan lainnya, memiliki ikatan emosi, terlibat dalam posisi sosial peran dan tugas-tugas yang saling berhubungan serta adanya rasa saling menyayangi dan memiliki (Sarafino, 2014).

Keluarga mempunyai peran dan tugas dibidang kesehatan yang perlu dipahami dan dilakukan yang meliputi mengenal masalah kesehatan, memutuskan tindakan yang tepat bagi keluarga, memberikan perawatan terhadap keluarga yang sakit, memodifikasi lingkungan keluarga untuk menjamin kesehatan keluarga, menggunakan pelayanan kesehatan (Sarafino,2014).

Salah satu hal yang bisa dilakukan oleh keluarga dalam membantu anggota keluarga yang mengalami halusinasi adalah dengan ikut berperan serta membantu klien untuk bisa mengontrol halusinasi, dan hal ini yang membuat keluarga juga perlu untuk mengetahui dan memahami dengan benar strategi pelaksanaan (SP) halusinasi, dan untuk bisa membantu meningkatkan peran keluarga tersebut, peran perawat juga diperlukan, salah satunya adalah memberikan health education atau intervensi strategi pelaksanaan keluarga yang benar yang bisa dilakukan oleh keluarga dirumah.

Strategi pelaksanaan tindakan keperawatan merupakan alat yang dijadikan sebagai panduan oleh seorang perawat jiwa ketika berinteraksi dengan kli en dengan gangguan halusinasi. Strategi pelaksanaan adalah penerapan standar asuhan keperawatan yang diterapkan pada pasien yang bertujuan untuk mengurangi masalah keperawatan jiwa yang ditangani. Strategi pelaksanaan pada pasien halusinasi mencakup kegiatan mengenal halusinasi, mengajarkan pasien bercakap-cakap dengan orang lain saat halusinasi muncul, serta melakukan aktifitas terjadwal untuk mencegah halusinasi (Sarafino, 2014).

Berdasarkan data awal yang diperoleh dari rekam medik dan observasi penelitian di RSJK Daerah Soeprapto Provinsi Bengkulu terdapat jumlah pasien gangguan jiwa di RSJK Daerah Soeprapto Provinsi Bengkulu pada tahun 2012 berjumlah 1.738 orang dengan pasien skizofrenia berjumlah 810 orang. Pada tahun 2013 terjadi peningkatan berjumlah 2.475 orang dengan pasien skizofrenia berjumlah 1.200 orang. Pada tahun 2014 menurun menjadi 1.994 orang dengan jumlah pasien skizofrenia berjumlah 920 orang. Dan pada tahun 2015 mengalami penurunan berjumlah 1.962 dengan jumlah pasien skizofrenia yaitu berjumlah 740 orang. Dapat disimpulkan bahwa pasien RSJK Daerah Soeprapto Bengkulu sudah banyak yang pulang kerumah masing-masing, akan 
tetapi masih dalam perawatan keluarga yang mendampingi pasien tersebut, karna ditakutkan mengalami kekambuhan kembali.

Berdasarkan survei awal yang dilakukan peneliti di temukan selama 2 hari wawancara kepada keluarga pasien 10 orang yang terdiri dari 8 0rang yang belum mengetahui strategi pelaksanaan keluarga dalam merawat pasien halusinasi dan 2 orang yang sudah mengetahui cara merawat pasien halusinasi. Terdapat empat ruangan yangt di observasi oleh peneliti dengan jumlah pasien rawat inap sebanyak 146 orang pasien dengan skizofrenia. Pasien dengan diagnosa keperawatan pada halusinasi pada tahum 2015 berjumlah 94 orang pasien. Pada tahun 2016 pasien dengan diagnosa keperawatan pada halusinasi pendengaran ruang Murai A berjumlah 17 orang, Murai B berjumlah 19 orang, Murai $\mathrm{C}$ berjumlah 22 orang, dan jumlah ruang Anggrek berjumlah 16 orang. Pasien dengan diagnosa keperawatan pada halusinasi pendengaran pada bulan febuari tahun 2017 berjumlah 75 orang. Tujuan penelitian ini diketahui pengaruh intervensi strategi pelaksanaan halusinasi terhadap pengetahuan dan kemampuan keluarga dalam merawat klien skizofrenia dengan halusinasi.

\section{METODE PENELITIAN}

\section{Desain Penelitian}

Desain penelitian yang digunakan dalam penelitian ini adalah pre-exsperimen dengan desain penelitian "one-group pre-test and post-test design" diaman penelitian ini dialkukan dengan cara memberikan pre tes (pengamatan awal) terlebih dahulu sebelum diberikan intervensi/perlakuan kemudian diberikan intervesni strategi pelaksanaan keluarga, selanjutnya dilakukan observasi kedua (post test) yaitu sesudah diberikan intervensi.

\section{Tempat Penelitian}

Penelitian ini dilakukan di RSKJ Soeprapto Bengkulu untuk mendapatkan alamat lengkap klien dan selanjutnya penelitian dilanjutkan dengan melakukan kunjungan ke rumah-rumah klien skizofrenia. Waktu penelitian dilaksanakan dari bulan AprilAgustus 2019.

\section{Populasi dan Sampel}

Populasi dalam penelitian ini adalah seluruh keluarga yang dinyatakan mendampingi anggota keluarganya yang mengalami gangguan jiwa skizoprenia dengan halusinasi. Sampel Penelitian ini adalah seluruh keluarga yang mendampingi anggota keluarganya yang mengalami gangguan jiwa halusinasi tahun 2019 dari bulan AprilAgustus yang berjumlah 15 orang.

\section{Teknik Pengambilan Sampel}

Teknik Pengambilan sampel menggunakan teknik nonprobability sampling yaitu apabila setiap subjek dalam populasi tidak mempunyai kesempatan yang sama untuk terpilih atau tidak terpilih sebagai sampel, rancangan yang digunakan adalah purposive sampling yaitu cara pengambilan sampel berdasarkan kriteria general.

\section{Instrumen Penelitian}

Instrumen penelitian digunakan adalah kuesioner, terdiri dari kuisioner tentang pengetahuan keluarga dan kemampuan keluarga. Pengumpulan data dilakukan dalam dua periode yaitu: melakukan pre test pada responden dan intervensi untuk menilai 
pengetahuan dan kemampuan keluarga, setelah itu diukur kembali pengetahuan dan kemampuan keluarga dalam merawat klien skizofrenia dengan halusinasi dengan menggunakn post test.

Analisis data dilakukan menggunakan 2 uji yaitu univariat untuk mengetahui distribusi frekuensi pengetahun dan kemapuan keluarga sebelum dan sesudah intervensi dan uji bivariat menggunakan analisis paired t-test.

\section{HASIL PENELITIAN}

Analisis Univariat

Anlisis univariat bertujuan untuk melihat distribusi dan persentase variabel independen dan variabel dependen, yaitu distribusi frekuensi pengetahuan dan kemampuan keluarga yang merawat klien skizofrenia dengan halusinasi sebelum dan sesudah diberikan intervensi strategi pelaksaan keluarga.

Tabel. 1

Distribusi Frekuensi Pengetahuan Keluarga Sebelum Diberikan Intervensi

\begin{tabular}{ccc}
\hline $\begin{array}{c}\text { Pengetahuan } \\
\text { Keluarga }\end{array}$ & Jumlah & Persentase \\
\hline Tahu & 1 & 6,7 \\
Tidak tahu & 14 & 93,3 \\
Total & 15 & 100 \\
\hline
\end{tabular}

Distribusi pengetahuan keluarga untuk kategori tahu yaitu 1 orang $(6,7 \%)$ dan kategori tidak tahu 14 orang $(93,3 \%)$

Tabel. 2

Distribusi Frekuensi Pengetahuan Keluarga Sesudah Diberikan Intervensi

\begin{tabular}{ccc}
\hline $\begin{array}{c}\text { Pengetahuan } \\
\text { Keluarga }\end{array}$ & Jumlah & Persentase \\
\hline Tahu & 14 & 93,3 \\
Tidak tahu & 1 & 6,7 \\
Total & 15 & 100 \\
\hline
\end{tabular}

Distribusi pengetahuan keluarga untuk kategori tahu yaitu 14 orang $(93,3 \%)$ dan kategori tidak tahu 1 orang $(6,7 \%)$

Tabel. 3

Distribusi Frekuensi Kemampuan Keluarga Sebelum Diberikan Intervensi

\begin{tabular}{ccc}
\hline $\begin{array}{c}\text { Kemampuan } \\
\text { Keluarga }\end{array}$ & Jumlah & Persentase \\
\hline Mampu & 0 & 0 \\
Tidak mampu & 15 & 100,0 \\
Total & 15 & 100 \\
\hline
\end{tabular}

Distribusi kemampuan keluarga untuk kategori tidak mampu yaitu 15 orang (100\%). 
Tabel. 4

Distribusi Frekuensi Kemampuan Keluarga Sesudah Diberikan Intervensi

\begin{tabular}{ccc}
\hline Kemampuan & Jumlah & Persentase \\
Keluarga & 14 & 93,3 \\
Mampu & 1 & 6,7 \\
Tidak mampu & 15 & 100 \\
Total & & \\
\hline
\end{tabular}

Distribusi kemampuan keluarga untuk kategori mampu yaitu 14 orang (93,3\%) dan tidak mampu 1 orang $(6,7 \%)$

\section{Analisis Bivariat}

Analisis bivariat bertujuan untuk mengetahui apakah ada hubungan yang signifikan antara dua variabel atau uga bisa digunakan untuk mengetahui apakah ada perbedaan atau pengaruh yang signifikan.

Tabel. 5

Distribusi Rata-Rata Pengetahuan Keluarga

\begin{tabular}{cccccc}
\hline Variabel & Mean & SD & SE & P Value & N \\
\hline Pengetahuan & & & & & \\
Pre test & 0,07 & 0,258 & 0,067 & 0,000 & 15 \\
Post test & 0,93 & 0,258 & 0,067 & & \\
\hline
\end{tabular}

Rata-rata pengetahuan keluarga pada pengukuran pertama 0,07 \% dengan standar deviasi 0,258. Pada pengukuran kedua di dapat rata-rata pengetahuan keluarga adalah $0,93 \%$ dengan standar deviasi 0,258. Hasil uji statistik di dapatkan nilai P 0,000 maka dapat disimpulkan ada perbedaan yang signifikan antara pengetahuan keluarga sebelum dan sesudah intervensi.

Tabel. 6

Distribusi Rata-Rata Kemampuan Keluarga

\begin{tabular}{cccccc}
\hline Variabel & Mean & SD & SE & P Value & N \\
\hline Kemampuan & & & & & \\
Pre test & 0,00 & 0,000 & 0,000 & 0,000 & 15 \\
Post test & 0,93 & 0,258 & 0,067 & & \\
\hline
\end{tabular}

Rata-rata kemampuan keluarga pada pengukuran pertama 0,00 \% dengan standar deviasi 0,000. Pada pengukuran kedua di dapat rata-rata pengetahuan keluarga adalah $0,93 \%$ dengan standar deviasi 0,258. Hasil uji statistik di dapatkan nilai P 0,000 maka dapat disimpulkan ada perbedaan yang signifikan antara kemampuan keluarga sebelum dan sesudah intervensi.

\section{PEMBAHASAN}

\section{Pengetahuan Keluarga Sebelum Diberikan Intervensi Strategi Pelaksanan Keluarga}

Berdasarkan hasil penelitian menunjukkan bahwa sebelum diberikan intervensi dapat diketahui rendahnya pengetahuan keluarga dalam merawat klien skizofrenia dengan halusinasi. Hasil penelitian ini sejalan dengan penelitian yang dilakukan oleh 
Yuliza tahun 2011, dar hasil penelitiaannya rendahnya tingkat pengathuan keluarga dalam merawat klien yaitu karena dipengaruhi faktor ekonomi dan pendidikan.

Menurut pendapat Notoatmodjo (2010) mengatakan bahwa salah satu faktor yang mempengaruhi pengetahuan adalah pendidikan. Pada umumnya pendidikan itu akan mempertinggi taraf intelegensi individu tersebut. Pengetahuan pada keluarga klien Skizofrenia adalah hasil dari tahu dan memahami setelah orang melakukan penginderaan terhadap suatu objek tertentu.

Keluarga diharapkan dapat lebih mengerti, mengetahui dan memahami yang pada akhirnya dapat berperan secara katif sebagai pendukung utama bagi klien yang juga akan meningkatkan kemampuan penyesuaian dirinya serta tidak rentan lagi terhadap pengaruh stressor psikososial. Upaya untuk meningkatkan pengetahuan pada keluarga klien skizofrenia perlu diberikan melalui penyuluhan dan pendidikan kesehatan, baik yang dilakukan seara langsung maupun tidak langsung. Sesuai dengan penelitian Saragih (2014) yang menyatakan bahwa hasil penelitiannya menunjukkan bahwa pengetahuan responden tentang perawatan anggota keluarga Skizofrenia dengan perilaku kekerasan di rumah adalah kurang. Hampir separuh responden memiliki pengetahuan yang kurang, sehingga dikhawatirkan hal ini akan menyulitkan keluarga dlaam mengatasi, menjaga salah satu keluarga mereka yang mengalami gangguan jiwa.

\section{Pengetahuan Keluarga Setelah Diberikan Intervensi Strategi Pelaksanan Keluarga}

Hasil penelitian dari pengetahuan 15 orang keluarga setelah diberikan intervensi di dapatkan sebagian besar responden memiliki pengetahuan dengan kategori tahu. Dari penelitian ini menunjukkan bahwa adanya peningkatan pengetahuan keluarga setelah diberikan intervensi strategi pelaksanaan keluarga dalam merawat klien Skizofrenia dengan halusinasi. Intervensi strategi pelaksanaan merupakan instrumen panduan pelaksanaan intervensi keperawatan jiwa yang digunakan perawat sebagai acuan saat berinteraksi atau berkomunikasi secara terapeutik kepada klien dengan gangguan jiwa. (Lutfi, 2009).

Adapun tujuannya agar keluarga dapat terlibat dalam perawatan pasien baik di di rumah sakit maupun di rumah, keluarga dapat menjadi sistem pendukung yang efektif untuk pasien (Keliat, 2014). Hasil post test ini sejalan dengan dengan penelitian sebelumnya yaitu penelitian dari Suryaningrum (2013) pada hasil penelitiannya didapatkan pengetahuan klien skizofrenia meningkat $(67 \%)$ dan menurut penelitian Riyandini (2011) dalam penelitiannya menyebutkan bahwa tingkat pengetahuan pada keluarga klien skizofrenia sebagian besar adalah tinggi (55,6\%).

Menurut Notoatmodjo (2010) informasi yang diperoleh baik baik dari pendidkan formal maupun non formal dapat memberikan pengaruh jangka pendek sehingga menghasilkan perubahan atau peningkatan pengetahuan. Pendidkan no formal tersebut dapat mempengaruhi pengetahuan keluarga tentang cara merawat pasien Skizofrenia. Dapat disimpulkan bahwa jika pengetahuan keluarga tinggi maka akan meningkatkan kemampuan keluarga dalam memberikan perawatan pada pasien skizofrenia dengan halusinasi yang hasilnya akan optimal.

\section{Kemampuan Keluarga Sebelum Diberikan Intervensi Strategi Pelaksanan Keluarga}

Hasil penelitian kemampuan 15 orang keluarga klien sebelum diberikan intervensi adalah semuanya dikategorikan tidak mampu (100\%). Dari hasil penelitian dapat diketahui dari 15 responden itu semuanya belum memiliki kemampuan dalam merawat 
anggota keluarganya dan terkait dengan rendahnya pengetahuan keluarga dalam merawat klien. Kemampuan keluarga merupakan gabungan dari pengetahuan dan sikap keluarga dalam merawat klien Skizofrenia dengan halusinasi.

Penelitian ini didukung oleh Hernawaty (2009) bahwa rerata kemampuan kognitif keluarga dalam merawat klien gangguan jiwa sebesar 32,15, dan kemampuan psikomotor 32,55. Fontaine (2009) menyatakan bahwa kemampuan keluarga ditentukan oleh kemampuan untuk manajemen stres yang produktif. Kelelahan fisik dan emosi selama merawat anggota keluarga dengan gangguan jiwa sering melanda keluarga karena berkurangnya stress tolerance. Peneliti berpendapat bahwa ketidakmampuan keluarga bisa disebabkan karena keluarga mengalami kelelahan secara fisik maupun mental selama merawat anggota keluarganya yang mengalami halusinasi. Dampak yang dirasakan keluarga akibat halusinasi klien sangat mempengaruhi sikap keluarga dalam merawat klien sehingga kemampuan keluarga menjadi tidak baik.

\section{Kemampuan Keluarga Setelah Diberikan Intervensi Strategi Pelaksanan Keluarga}

Hasil penelitian kemampuan 15 orang keluarga klien setelah diberikan intervensi didapatkan sebagian besar termasuk dalam kategori mampu. Berdasarkan hasil penelitian ini terjadi peningkatan kemampuan yang signifikan setelah diberikan intervensi strategi pelaksanaan keluarga. Sejalan dengan peningkatan kemampuan keluarga dalam merawat pasien skizofrenia dengan halusinasi, perilaku keluarga dalam merawat pasien terbukti ikut mengalami peningkatan. Perubahan perilaku tidak sama dengan pengetahuan. Perubahan kemampuan memerlukan waktu yang lebih lama (Videbeck, 2011). Meskipun demikian perubahan keluarga dapat dilihat dari perhatian keluarga dalam pengobatan pasien. Keluarga tidak hanya mengantar pasien berobat saja, akan tetapi keluarga mulai memastikan bahwa obat diminum oleh pasien. Keluarga menjadi lebih memperhatikan waktu kontrol pasien. Keluarga juga mulai melibatkan pasien dalam aktivitas sehari-hari baik di rumah maupun di luar rumah. Komunikasi dalam keluarga mulai dilakukan sehingga beban yang dirasakan dalam merawat berkurang.

\section{Perbedaan Pengetahuan Keluarga Sebelum dan Sesudah Intervensi Strategi Pelaksanaan Keluarga}

Hasil penelitian menunjukkan bahwa terjadi peningkatan pengetahuan pada klien berdasarkan hasil uji pengetahuan keluarga sebelum dan sesudah intervensi. Peningkatan pengetahuan keluarga terjadi karena diberikannya intervensi strategi pelaksanaan keluarga pada keluarga dengan klien Skizofrenia dengan halusinasi.

Hasil ini sejalan dengan penelitian yang dilakukan Emma (2014) hasil peneitiannya menunjukkan adanya pengaruh pemberian penyuluhan kesehatan intervensi strategi pelaksanaan keluarga pada pasien Skizofrenia dengan resiko perilaku kekerasan terhadap pengetahuan keluarga dalam merawan anggota keluarga dengan gangguan jiwa.

Intervensi strategi pelaksanaan merupakan instrumen panduan pelaksanaan intervensi keperawatan jiwa yang digunakan perawat sebagai acuan saat berinteraksi atau berkomunikasi secara terapeutik kepada klien dengan gangguan jiwa (Lutfi, 2013). Adapun tujuannya agar keluarga dapat terlibat dalam perawatan pasien baik di di rumah sakit maupun di rumah, keluarga dapat menjadi sistem pendukung yang efektif untuk pasien (Keliat, 2014). 
Perbedaan yang signifikan ini terjadi karena adanya sikap terbuka keluarga dan keinginan mengetahui cara merawat anggota keluarga mereka dengan cara yang tepat. Keluarga merupakan faktor penting yang menentukan keberhasilan asuhan keperawatan pada pasien dengan halusinasi. Dukungan keluarga selama pasien di rawat di rumah sakit sangat dibutuhkan sehingga pasien termotivasi untuk sembuh. Demikian juga saat pasien tidak lagi dirawat di rumah sakit (dirawat di rumah). Keluarga yang mendukung pasien secara konsisten akan membuat pasien mampu mempertahankan program pengobatan secara optimal. Namun demikian jika keluarga tidak mampu merawat pasien, pasien akan kambuh bahkan untuk memulihkannya lagi akan sangat sulit. Untuk itu perawat harus memberikan pendidikan kesehatan kepada keluarga agar keluarga mampu menjadi pendukung yang efektif bagi pasien dengan halusinasi baik saat di rumah sakit maupun di rumah (Keliat, 2014).

Tindakan keperawatan yang dapat diberikan untuk keluarga pasien halusinasi adalah: Diskusikan masalah yang dihadapi keluarga dalam merawat pasien, berikan pendidikan kesehatan tentang pengertian halusinasi, jenis halusinasi yang dialami pasien, tanda dan gejala halusinasi, proses terjadinya halusinasi, dan cara merawat pasien halusinasi. berikan kesempatan kepada keluarga untuk memperagakan cara merawat pasien dengan halusinasi langsung di hadapan pasien, memberikan pendidikan kesehatan kepada keluarga tentang perawatan lanjutan pasien.

\section{Perbedaan Kemampuan Keluarga Sebelum dan Sesudah Intervensi Strategi Pelaksanaan Keluarga}

Hasil penelitian menunjukkan bahwa ada perbedaan yang signifikan antara kemampuan keluarga sebelum dan sesudah intervensi. Penelitian yang dilaksanakan oleh tim WHO (2012) menunjukkan bahwa pemberian penyuluhan kesehatan dalam hal ini pemberian intervensi strategi pelaksanaan keluarga akan mempengaruhi masyarakat melakukan penyesuaian perilaku secara gradual terhadap konsep dan prosedur dalam melaksanakan perilaku hidup sehat, untuk itu dalam melakuksanakan penyuluhan kesehatan tidak boleh berhenti sebelum masyarakat benar-benar telah mengadopsi perilaku yang baru agar tidak terjadi kebingungan karena kurangnya referensi padasaat proses adopsi perilaku.

Sesuai dengan hasil penelitian tersebut, setelah diberikan intervensi strategi pelaksanaan keluarga maka kemampuan keluarga dalam merawat klien Skizofrenia dengan halusinasi meningkat dari tidak mampu menjadi mampu. Peningkatan kemampuna ini karena responden (keluarga) melakukan pembaharuan perilakunya sesuai dengan strategi penatalaksanaan halusinasi oleh keluarga, namun karena karena informasi yang baru diterima oleh responden dan frekuensinya baru sekali menyebabkan responden dalam proses adaptasinya belum sempurna, sehingga menimbulkan kesan terjadinya penurunan peran. Kondisi ini memerlukan pendampingan secara terus menerus kepada keluarga agar keluarga dapat dengan sepenuhnya melaksanakan strategi pelaksanaan halusinasi dan tidak berhenti ditengah jalan dan kemudian kembali melakukan perawatan dengan menggunakan pola yang lama. Menurut Mubarak (2009) health education dalam hal ini intervensi strategi pelaksanaan keluarga adalah sebuah proses yang berkelanjutan dalam upaya untuk menciptakan perilaku hidup sehat pada masyarakat.

Berdasarkan konsep tersebut terlihat bahwa intervensi strategi pelaksanaan keluarga tidak hanya bisa dilaksanakan sekali dua kali namun harus dilaksanakan secara berkelanjutan sampai masyarakat mengadopsi perilaku baru, termasuk dalam hal ini 
strategi pelaksanaan keluarga dengan klien Skizofrenia dengan halusinasi pada. Pemberian intervensi strategi pelaksanaan keluarga yang hanya sekali atau dua kali tidak memberikan manfaat secara langsung terhadap peran keluarga, namun hanya memberikan tambahan referensi, kondisi ini apabila tidak didorong kembali melalui intervensi stategi pelaksanaan keluarga yang berkelanjutan akan menimbulkan pertentangan antara konsep yang telah diberikan dengan pengalaman yang dihadapi oleh responden.

\section{SIMPULAN}

Distribusi frekuensi pengetahuan keluarga dengan klien Skizofrenia dengan halusinasi sebelum diberikan intervensi strategi pelaksanaan keluarga menunjukkan bahwa dari 15 orang keluarga yang menjadi responden didapatkan sebagian besar pengetahuan responden dengan kategori tidak tahu. Distribusi frekuensi pengetahuan keluarga dengan klien Skizofrenia dengan halusinasi setelah diberikan intervensi strategi pelaksanaan keluarga menunjukkan bahwa dari 15 orang keluarga yang menjadi responden didapatkan sebagian besar pengetahuan responden dengan kategori tahu.

Distribusi frekuensi kemampuan keluarga dengan klien skizofrenia dengan halusinasi setelah diberikan intervensi strategi pelaksanaan keluarga menunjukkan bahwa dari 15 orang keluarga yang menjadi responden didapatkan semua kemampuan keluarga dengan kategori tidak mampu. Distribusi frekuensi kemampuan keluarga dengan klien Skizofrenia dengan halusinasi sebelum diberikan intervensi strategi pelaksanaan keluarga menunjukkan bahwa dari 15 orang keluarga yang menjadi responden didapatkan sebagian besar kemampuan keluarga dengan kategori mampu.

Ada pengaruh intervensi strategi pelaksanaan keluarga terhadap pengetahuan dan kemampuan keluarga dalam merawat klien Skizofrenia dengan halusinasi.

\section{SARAN}

1. Keluarga Pasien

Diharapkan keluarga menerapkan pengetahuan dan kemampuan yang tepat untuk merawat klien Skizofrenia dengan halusinasi

2. Institusi Kesehatan

Dihapakan dapat menerapkan intervensi strategi pelaksaan keluarga secara berkelanjutan dalam merawat klien Skizofrenia dengan halusinasi

3. Peneliti Selanjutnya

Diharapkan kepada peneliti selanjutnya dapat melanjutkan penelitian ini dengan menggunakan kelompok kontrol, perlu melakukan penelitian lebih lanjut mengenai faktor-faktor seperti faktor ekonomi dan pendidikan, proses komunikasi dalam keluarga, beban keluarga, dan dukungan keuarga.

\section{DAFTAR PUSTAKA}

Emma, S. (2014). Faktor-Faktor yang Memengaruhi Pemasungan terhadap Penderita Skizofrenia di Kota Binjai Sumatera Utara. Diunduh tanggal 15 agustus 2019 di http://repository.usu.ac.id/bitstream/123456789/52304/7/Cover.pdf

Fontaine, K. L. (2009). Mental Health Nursing. Fifth Edition. Prentice Hall. Upper Saddle River

Hernawaty, T. (2009). Pengaruh Terapi Suportif terhadap Kemampuan Keluarga Merawat Klien Gangguan Jiwa di Kelurahan Bogor Barat. Tesis. Tidak dipublikasi 
Keliat, B A. (2014). Keperawatan Kesehatan Jiwa Komunitas: CMHN (Basic Course). Jakarta : Buku Kedokteran EGC

Kemenkes RI (2014). UU RI No. 18 Tahun 2014 tentang Kesehatan Jiwa. Jakarta: Kemenkes RI

Lutfi, I. (2009). Psikologi Sosial. Jakarta: Lembaga Penelitian UIN Ciputat

Mubarak \& Chayatin. (2009). Pendidikan Kesehatan. Jakarta: EGC

Notoatmodjo, S. (2010). Metodologi Penelitian Kesehatan. Jakarta: Rineka Cipta

Riset Kesehatan Dasar. (2013). Badan Penelitian dan Pengembangan Kesehatan Kementerian RI tahun 2013. Diakses: 19 Agustus 2018, dari http://www.depkes.go.id/resources/download/general/Hasil\%20Riskesdas\%20201 3.pdf

Sarafino, E. P., \& Smith, T. W. (2014). Health Psychology Eight Edition. USA: John Wiley \& Sons, Inc

Saragih., Sasmaida (2014). Gambaran Tingkat Pengetahuan dan Sikap Keluarga tentang Perawatan Pasien Resiko Perilaku Kekerasan di Rumah. Jurnal Online mahasiswa Bidang Ilmu Keperawatan, 1(1)

Suryaningrum \& Yuliawardhani. (2013). Hubungan antara Beban Keluarga dengan Kemampuan Keluarga Merawat Pasien Perilaku Kekerasan di Poliklinik Rumah Sakit Marzoeki Mahdi Bogor. Jurnal Keperawatan Jiwa, 1(2), 148-55

Videbeck \& Sheila. L. (2011). Psychiatric Mental Health Nursing. Fifth Edition. Lippincott Williams \& Wilkins

World Health Organization. (2012). Kesehatan Jiwa. Amerika: WHO

Yosep, I. (2013). Keperawatan Jiwa (Edisi Revisi). Bandung: Refika Aditama 